\title{
НАВЧАННЯ КРЕАТИВНОГО ПИСЬМА НА \\ ЗАНЯТТЯХ 3 ІНОЗЕМНОЇ МОВИ ЯК ЗАСІБ ФОРМУВАННЯ КОМУНІКАТИВНОЇ КОМПЕТЕНЦІї СТУДЕНТІВ
}

\footnotetext{
У статті розглянуто навчання креативного письма на заняттях з іноземної мови як засіб формування комунікативної компетенції студентів, конкретизовано поняття "креативне письмо», «навчання креативного письма», виокремлено етапи його реалізаиії.

Ключові слова: креативне письмо, комунікативна компетенція, навчання, етапи.
}

В статье рассмотрено обучение креативному письму на занятиях по иностранному языку как средство формирования коммуникативной компетенции студентов, конкретизированы понятия «креативное письмо», «обучение креативному письму», выделены этапы его реализаиии.

Ключевые слова: креативное письмо, коммуникативная компетенция, обучение, этапы.

The article deals with teaching creative writing at the English lessons as the means of forming students' communicative competence. The notions «creative writing», «teaching creative writing» are concretized. The stages of its realization are singled out.

Key words: creative writing, communicative competence, teaching, stages.

Сучасні інтеграційні процеси зумовлюють зростання інтересу до вивчення іноземних мов i, відповідно, стимулюють пошуки нових підходів, більш ефективних методик навчання. «Освіта ХХІ ст. - це освіта для людини. Основою іiі є розвивальна, культуротворча домінанта, виховання відповідальної, здатної до самоосвіти й саморозвитку особистості, яка вміє критично мислити, опрацьовувати різноманітну інформацію, використовувати набуті знання і вміння для творчого розв'язання проблем» Г2].

Серед видів мовленнєвої діяльності (говоріння, аудіювання, читання і письмо), визначених метою навчання іноземної мови Державним освітнім стандартом 3 іноземної мови [1], письмо посідає особливе місце. По-перше, це часто пов'язано із відношенням до нього як до інструменту для оволодіння іноземною мовою, а не як до мети навчання. По-друге, опанування зв'язним писемним мовленням передбачає не тільки високий рівень розвитку вмінь спілкування іноземною мовою, але й уміння творчо, критично, логічно та послідовно висловлювати власні думки.

Включення креативного письма до навчання студентів творчого писемного мовлення є одним 3 пріоритетних напрямів у системі навчання студентів іноземної мови у ВНЗ на сучасному етапі розвитку суспільства.

У психологічному та психолінгвістичному аспектах проблема писемного мовлення розглядалася багатьма відомими вченими. Серед них Є. Бабушис, Б. Бєляєв, Л. Виготський, М. Гец, А. Давиденко, I. Зимня, К. Лазаренко, О. Леонтьєв, О. Лурія, Л. Мазунова, С. Ніколаєва, Т. Рябова, Г. Тейлор, I. Торренс та інші. Однак питанню навчання креативного письма на заняттях з іноземної мови, виокремлення етапів його реалізації у вітчизняній методичній літературі не приділено належної уваги.

Тому метою статті є дослідити переваги навчання креативного письма на заняттях з іноземної мови для розвитку комунікативної компетенції студентів, виокремити етапи його реалізації та запропонувати приклади вправ, характерних для кожного з етапів.

Письмо - найбільш складний вид мовленнєвої діяльності навіть для носіїв мови, тому що воно реалізується в умовах відсутності адресата та неможливості використання адресантом паралінгвістичних засобів (інтонаційної виразності, тембру, міміки, жестів тощо). Отже, завданням того, хто навчається, повинно бути доведення його до певного рівня досконалості 3 точки зору організації писемного висловлювання, його повноти й розгорнутості, логічності, граматичного оформлення.

На сучасному етапі можна виокремити три навчальні можливості писемного мовлення, які, на жаль, рідко розглядаються в комплексі:

1. Письмо - діяльність, яку можна самостійно контролювати (на відміну від говоріння). Під час процесу письма студент читає власний твір. Це створює простір для з'ясування правильності не тільки граматичної, що відноситься до тексту, а й змістовного аспекту висловлювання.

2. Письмо здійснюється 3 перервами, кожна перерва - можливість варіативно, комплексно висловити власну думку. Таким чином, письмо створює відчуття свободи.

3. Письмо удосконалює психічні якості людини. Під час письма студент закріплює слова, форми, вислови, речення в пам'яті.

В основу створення практично всіх форм письмового повідомлення покладено такі вміння, як:

- передача основної інформації (основного змісту), головної ідеї;

- опис, порівняння, зіставлення; 
- аргументація;

- комбінування фактів;

- характеристика, оцінка, висловлювання власного ставлення, реферування, коментування тощо.

Метою навчання письма $€$ формування у студентів комунікативної компетенції, яка включає володіння письмовими знаками, вміння грамотно побудувати зміст та форму писемного мовлення.

Особливого значення сьогодні набуває методика креативного письма на заняттях з іноземної мови.

У сучасній методиці викладання іноземних мов академічне письмо часто розуміють як креативне. Насправді студент у процесі написання ессе використовує свої творчі здібності, викладає власну думку, аргументує, порівнює, описує події і явища. Але важливим для викладача є розуміння, що навчання академічного та креативного письма вимагає різних підходів, методик проведення та технологій. Це пов'язано насамперед із природою креативності, яка полягає у зміщенні акцентів у бік самовираження, творчості, фантазії, уяви.

Креативне письмо - це особливий вид твору, який передбачає нестандартність мислення автора.

Під «навчанням креативного письма» розуміють вправи продуктивного характеру різного ступеню складності, різні за формою та змістом, наприклад, ігрової форми.

Найбільш поширеними формами креативного письма науковці вважають такі: автобіографія/мемуари, журналістські ессе, роман, новела, драматичні твори, поетичні твори, тексти пісень.

Навчання креативного письма студентів здійснюється послідовно в три етапи.

Метою початкового етапу є формування навичок реалізації письмової мовленнєвої діяльності як креативної.

Мета етапу впровадження - розвиток аналітичних умінь та вмінь структурно-семантичної та лінгвістичної реорганізації іншомовного креативного тексту.

Метою завериального етапу навчання креативного письма $є$ розвиток і вдосконалення вмінь складання креативного іншомовного тексту.

Навчання креативного письма студентів ВНЗ реалізується за допомогою спеціальної системи вправ, в основу якої покладено евристичні прийоми пізнання об'єкта, виявлення його основних якостей та евристичні прийоми створення нового об'єкта.

Розроблена система включає в себе три типи вправ: підготовчі, репродуктивні та продуктивні.

Підготовчі вправи орієнтовані на ознайомлення студентів із різними евристичними прийомами. У процесі виконання цих вправ студенти навчаються використовувати евристичні прийоми для написання невеликих за обсягом креативних текстів.

Викладач, визначивши обсяг, рівень складності навчального матеріалу, подає його у формі евристичної бесіди, дискусії чи дидактичної гри, поєднуючи часткове пояснення матеріалу 3 постановкою проблемних питань, пізнавальних завдань чи експерименту. Це спонукає студентів до самостійних відкриттів, оволодіння прийомами активного мовленнєвого спілкування, постановки й розв’язання навчальних проблем.

Важливо при цьому пояснити матеріал, який студенти не можуть засвоїти самостійно, формуючи високий рівень проблемності, властивий діяльності в новій ситуації, коли алгоритм дії невідомий. У такій діяльності мають переважати логічні процедури аналізу, порівняння, узагальнення.

Наведемо приклади завдань етапу впровадження навчання креативного письма:

1. Доберіть асоціації (складіть асоціативний ланцюжок) зі словами (словосполученнями): «Environment», «Pollution», «Smog», «Natural Resources», «Acid Rains».

2. За 5 хвилин дайте версії розв'язання екологічної проблеми сьогодні.

3. Побудуйте логічний причинно-наслідковий ланцюжок i сформулюйте низку послідовних суджень: «the development of modern technologies, the invention of plastic, the improvement of service at supermarkets, the lack of recycling technologies, the lack in educational programs, pollution of the environment, the death of life on the earth».

4. Гармонійно розвинена освічена особистість не може бути закостенілою у своїх поглядах. Вона завжди повинна бачити у будь-якому феномені неоднозначність, тому мета цього виду діяльності полягає в тому, щоб заохотити студентів до пошуку позитивних особливостей $(П=$ плюс), негативних особливостей (M = мінус) та цікавих моментів (Ц = цікавий) даного феномену, ситуації. Цікаві моменти не можуть бути позитивними або негативними, їх просто важливо відзначити.

Завдання студентів скласти список усіх «плюсів», «мінусів» та цікавих моментів 3 питання за 5-10 хвилин.

Приклади «PMI»- Statements:

- $\quad$ In the nearest future there will be no nuclear power stations.

- $\quad$ The local government decides to get rid of all homeless animals.

- $\quad$ In ten years' time the climate in Ukraine will become as hot as in Egypt.

Репродуктивні вправи є письмовими креативними завданнями, які сформульовано на основі евристичних прийомів із залученням уяви (фантазіі).

Приклади репродуктивних вправ: 
1. Read the chapter «Roger's First Day at School». Write down Chapter Two of the story imitating the author's style.

2. Watch the film «Dead Poets' Society». Write your own version of the end of the film.

Продуктивні вправи передбачають складання казки, короткого оповідання або вірша з опорою на наочність та без опори. Наочність при цьому виступає стимулом креативної письмової діяльності. Вправи без використання наочності являють собою проблемні ситуації, які сформульовано як теми для написання креативних письмових робіт.

1. Close your eyes briefly. Think of an object that is in the room and focus on it. Without opening your eyes, recall as much detail as you can about it. After 3 minutes or so, open your eyes and write about that object without looking at it.

2. Use the following words in your story: a little boy, a torn page, a cart.

3. Start your story with the line: Her laugh broke the silence.

4. Write from the point of view of a wedding bouquet.

5. Use this plot in a short story: room-mates have not paid the phone bill.

6 . Write from the point of view of the last tree in the forest.

Доцільно зазначити, що використання евристичних прийомів пізнання об'єкта, виявлення його основних якостей та евристичних прийомів утворення нового об'єкта в якості основи системи спеціальних вправ у креативному письмі, а також включення до неї завдань, спрямованих на розвиток творчих здібностей (здібності до аналізу та синтезу, здібності виявляти нові проблеми в традиційній ситуації, здібності мислити асоціаціями, здібності генерувати велику кількість ідей), підвищують творчу активність студентів і сприяють формуванню конкурентоспроможної особистості майбутнього спеціаліста.

Оволодіння креативним письмом підвищує рівень мовленнєвої свідомості та культури студентів, їхньої мотивації, стимулює розвиток основних видів мовленнєвої діяльності, позитивно впливаючи на процес навчання іноземної мови у ВНЗ.

1. Державний освіній Література

1. Державний освітній стандарт з іноземної мови / Керівн. автор. колективу С. Ю. Ніколаєва. - К. : Ленвіт, 1998. - 32 с. 2. Концепція загальної середньої освіти (12-річна школа) // Педагогічна газета. - 2002. - № 1 (91). 